\title{
SPECIFIC TREATMENT OF HEPATOSPLENIC SCHISTOSOMIASIS CAN INCREASE T-LYMPHOCYTE REACTIVITY
}

\author{
Maria Imaculada Muniz-Junqueira, José Tavares-Neto, \\ Meire Ataide, Aluízio Prata and Carios Eduardo Tosta
}

\begin{abstract}
It has been recognized that Schistosoma mansoni infection causes depression of T-cell responsiveness. In this study we have evaluated whether immunodepression associated to schistosomiasis could be reverted by specific treatment. $T$-cell immune response was assessed by means of intradermal tests using recall antigens in a group of 22 patients with hepatosplenic schistosomiasis, one year after treatment with oxamniquine and compared with a group of untreated hepatosplenic patients. Only $27 \%$ of treated patients presented complete anergy to all tested antigens, in marked contrast to $80 \%$ unresponsiveness showed by hepatosplenic patients without treatment. Although most of the treated individuals showed some response to the tested antigens, in some individuals this unresponsiveness still persisted after treatment. Anergy was not found in any normal individual of the control group. It was concluded that Schistosoma mansoni infected patients may recover their normal immune responsiveness after the elimination of the worm by treatment.
\end{abstract}

Key-words: Immunodepression. Schistosomiasis. Oxamniquine.

It is well established that infection by Schistosoma mansoni results in a depressed function of $T$ lymphocytes 36 . This immunodepression may be both specific ${ }^{4} 9$ or unrelated to the antigens of schistosoma worm 1011 18. The non-specific immunodepression may represent a serious constraint to the elimination of intracellular pathogens in these patients 13 .

T-lymphocyte immunodepression in patients with schistosomiasis has been related to the worm burden 18 and can be induced by the administration of worm membrane preparation to non-infected mice ${ }^{16}$.

It is therefore possible that $T$-lymphocyte immunodepression to unrelated antigens in Schistosoma-infected patients may be reverted by the elimination of the worm by means of specific therapy.

This work aimed to evaluate in vivo T-lymphocyte response to unrelated antigens in patients with hepatosplenic schistosomiasis after the elimination of the worm by specific therapy.

Núcleo de Medicina Tropical e Nutrição e Laboratório de Imunologia Celular, Faculdade de Ciências da Saúde, Universidade de Brasília, Brasília, DF.

Faculdade, de Medicina do Triângulo Mineiro, Uberaba, MG.

Grants: CNPq (Proc. 40.1041/PIDE VI and 40.1868/87).

Address for correspondence: Dra Maria Imaculada MunizJunqueira, Laboratório de Imunologia, Departamento de Patologia/FCS/UnB. 70910 Brasilia, DF, Brasil.

Recebido para publicação em 22/01/91.

\section{MATERIAL AND METHODS}

The ethical rules of the Helsinki Declaration 12 were strictly followed throughout this investigation.

Twenty two patients of both sexes and $35 \pm 14$ years old with hepatosplenic schistosomiasis were studied. Most of them (55\%) were Caucasians. All patients had been previously treated with a single oral dose of $15 \mathrm{mg} / \mathrm{kg}$ of oxamniquine.

The diagnosis of schistosomiasis was previously established on clinical and parasitological grounds. Eggs of Schistosoma mansoni were detected in faeces by the Kato-Katz method ${ }^{14}$. Parasitological assessment of cure was performed after treatment, by the absence of $S$. mansoni eggs in at least three examination of the faeces. The clinical criteria for the diagnosis of hepatosplenic schistosomiasis were those described by Pratal ${ }^{19}$. Physical examination showed no signs of clinical decompensation or nutritional imbalance. Another three patients, not belonging to the previous group and who had been previously splenectomized, were also treated with oxamniquine and submitted to the tests. They also did not show any $S$. mansoni-eggs in faeces.

The positive control group was formed by five female, $21 \pm 8$ years old patients with hepatosplenic schistosomiasis. All of them were passing $S$. mansonieggs in faeces. Ten healthy individuals, of both sexes, $26 \pm 5$ years old, $70 \%$ of them Caucasians, were considered as the negative control group.

T-lymphocyte function was evaluated by intradermal tests, using the recall antigens candidin, PPD, streptokinase-streptodornase, trichophytin and vaccinia virus (Allergofar). The later was exclusively used in those individuals showing a scar of smallpox vaccine. One tenth of $\mathrm{ml}$ of antigen solution was intradermally injected in the undersurface of the left forearm. Induration was read 48 hours later, and. 
considered as positive when the largest diameter was equal or higher than $5 \mathrm{~mm}^{20}$.

The results were statistically analysed by the Chi-square test and Fisher's exact test.

\section{RESULTS}

Only six out of 22 schistosomiasis patients without $S$. mansoni eggs in faeces $(27 \%)$ showed a complete unresponsiveness to all applied intradermal antigens, while 4 out of 5 patients still passing eggs showed anergy. This difference was statistically significant $(p<0.05)$. However, both groups of schistosomiasis individuals showed a higher frequency of anergic tests, when compared to those of the normal control group, where no anergic individual was found (Table 1).

Table 1 - Response of individuals with active hepatosplenic schistosomiasis (HS), of previously treated $H S$ patients and of normal individuals to recall antigens by intradermal tests.

\begin{tabular}{lrlc}
\hline Groups & \multirow{2}{*}{} & \multicolumn{2}{c}{ Anergy to all applied antigens } \\
\cline { 3 - 4 } & & number & $\%$ \\
\hline Normal & 10 & $0 / 10$ & 0 \\
Active HS & 5 & $4 / 5^{*}$ & 80 \\
Treated HS & 22 & $6 / 22^{*} / *$ & 27 \\
\hline
\end{tabular}

- Significantly different from normal group $(p<0.05)$. Fisher's Exact Test.

* Significantly different from active HS group $(p<0.05)$. Chi-square test.

Twenty one out of the 105 intradermal tests applied in the schistosomiasis group without worm were positive (20\%), whereas only one test out of 20 (5\%) showed positivity in the group presenting worms. However, both groups showed a significantly decreased number of positive responses when compared with those of normal individuals (57\%) (Table 2).

Table 2 - Positivity of the response to recall antigens by intradermal tests of patients with active hepatosplenic (HS) schistosomiasis, of previously treated HS patients and normal individuals.

\begin{tabular}{lrc}
\hline Groups & \multicolumn{2}{c}{ Positivity of response } \\
& N & $\%$ \\
\hline Normal & $25 / 44$ & 57 \\
Active HS & $1 / 20$ & $5^{*}$ \\
Treated HS & $21 / 105$ & $20^{*}$ \\
\hline
\end{tabular}

- Significantly different from normal group $(p<0.05)$. Chi-square Test.

None of the three splenectomized patients showed anergy and six out of the 15 tests applied (40\%) showed positivity.

\section{DISCUSSION}

Schistosoma mansoni-infected patients may present T-lymphocyte-dependent immunodepression and this could make difficult the elimination of intracellular pathogens as observed in prolonged septicaemic salmonellosis associated with schistosomia$\operatorname{sis}^{22}$. The immunodepression is related to the worm burden. Thus, it can be postulated that the elimination of $S$. mansoni by means of specific therapy would help recovering normal immune responsiveness.

Our data showed that hepatosplenic individuals, considered to be cured by chemotherapy, presented a lower degree of T-cell immunodepression than those who were actively passing $S$. mansoni eggs in faeces. In support to our data are the observations of AbdelSalam et $\mathrm{al}^{1}$ and Barsoum et al ${ }^{4}$ who showed increased in vitro proliferative responses of lymphocytes to mitogens or antigens, after specific treatment of Schistosoma-infected patients. It has also been demonstrated in mice infected with $S$. mansoni ${ }^{21}$ or $S$. haematobium ${ }^{15}$ an increased reactivity of lymphocytes after treatment with praziquantel.

Our results also indicated that the recovery of Tcell reactivity was not complete in some treated individuals. Although the reasons for that are not known, it is possible to speculate that it could be related to the degree of previous involvement of the immune system due either to the duration of the infection, the worm burden or the peculiar response of each individual. In fact, Tawfik et $\mathrm{al}^{21}$ have showed in mice that the duration of infection prior to treatment was a determining factor in the subsequent expression of immunoreactivity. Butterworth et $\mathrm{al}^{7}$ have also showed in S. mansoni-infected patients that the resistance to reinfection after specific therapy depended on the duration of previous infection.

The low frequency of individuals with T-lymphocyte immunodepression amongst treated patients points to the possibility that factors related to the presence of $S$. mansoni may play a causal role. In fact, it has been showed that injections of worm membrane preparation induces immunodepression in normal mice ${ }^{16}$ and, in patients, this immunodepression is related to the worm burden ${ }^{18}$. However, other factors can also be implicated in the development of this immunodepression, since the elimination of the worm is not enough to completely revert immunodepression. It is possible that factors related to the alterations of the structure and functions of the liver and spleen during the infection, which can persist after treatment ${ }^{2} 8$ may play a role in this immunodepression. In fact, our limitated observation of three patients previously splenectomized and treated with oxaminiquine showed that none of them presented with anergy to all antigens, and the number of positive responses to intradermal tests was similar to that of the normal individuals. Besides, it has been showed that immunodepression is related to the spleen size ${ }^{17}$.

The specific treatment may benefit Schistosoma-infected patients both by the elimination of the worm, and by the reversion of the immunodepression. It can also decrease the spleen size ${ }^{5}$, which may be related with immunodepression. 
Muniz-Junqueira MI, Tavares-Neto J, Ataíde M, Prata A, Tosta CE. Specific treatment of hepatosplenic schistosomialsis can increase Tlymphocyte reactivity. Revista da Sociedade Brasileira de Medicina Tropical 24: 97-99, abr-jun. 1991

\section{RESUMO}

Tem sido observado que infecção por Schistosonı. mansoni pode causar imunodepressâo celular. Neste trabalho fai avaliado se a imunodepressão associada à esquistossomose pode ser revertida pelo tratamento especifico. $A$ resposta imune celular foi determinada através de testes cutâneos de hipersensibilidade retardada em 22 pacientes com a forma hepatoesplênica da esquistossomose um ano após tratamento com oxamniquine e comparado com aquela observada em um grupo de pacientes hepatoesplénicos náo tratados. Somente $27 \%$ destes pacientes apresentaram alergia a todos os antígenos testados, em contraste com $80 \%$ de individuos anérgicos observados entre aqueles não tratados. Embora a maioria dos individuos tratados tenha mostrado algum grau de resposta aos antigenos testados, alguns indivíduos permaneceram anérgicos após o tratamento especifico. Anergia a todos os antigenos aplicados não foi observada em nenhum dos individuos normais. Nossos dados indicam que pacientes esquistossomóticos podem recuperar sua reatividade imune após a eliminacāo do verme pelo tratamento especifico. mose. Oxamniquine.

Palavras-chaves: Imunodepressão. Esquistosso-

\section{ACKNOWLEDGEMENTS}

The authors gratefully acknowledge the assistance of Rodolfo Gomes de Oliveira and Joaquim Cândido de Lima during field work.

\section{REFERENCES}

1. Abdel-Salam E, Higashi GI, Kamal KA, Ishaac S. Cellmediated immune assay in children with Schistosoma haematobium infection and the effect of niridazole therapy. Transactions of the Royal Society of Tropical Medicine and Hygiene 75: 207-214, 1981.

2. Andrade ZA, Grimaud JA. Evolution of the schistosomal hepatic lesions in mice after curative chemotherapy. American Journal of Pathology 124: 59-65, 1986.

3. Andrade ZA, Warren KS. Mild prolonged schistosomiasis in mice: alterations in host response with time and the development of portal fibrosis. Transactions of the Royal Society of Tropical Medicine and Hygiene 58: 53$57,1964$.

4. Barsoum IS, Gamil FM, Al-Khafif MA, Ramzy RM, El Alamy MA, Colley DG. Immune responses and immunoregulation in relation to human schistosomiasis in Egypt. I. Effect of treatment on in vitro cellular responsiveness. The American Journal of Tropical Medicine and Hygiene 31: 1181-1187, 1982.

5. Bina JC, Prata A. Regressão da hepatotosplenomegalia pelo tratamento especifico da esquistossomose. Revista da Sociedade Brasileira de Medicina Tropical 16: 213$218,1983$.

6. Boros DL, Pelley RP, Warren KS. Spontaneous modulation of granulomatous hypersensitivity in schistosomiasis mansoni. Journal of Immunology 114: 1437$1441,1975$.

7. Butterworth AE, Capron M, Cordingley JS, Dalton PR, Dunne DW, Kariuki HC, Kimani G, Koech D, Mugambi M. Ouma JH, Prentice MA, Richardson BA, Arap Siongok TK, Sturrock RF, Taylor DW. Immunity after treatment of human schistosomiasis mansoni. II. Identification of resistant individuals, and analysis of their immune responses. Transactions of the Royal Society of Tropical Medicine and Hygiene 79: 393-408, 1985.

8. Cheever AW, Deb S. Persistence of hepatic fibrosis and tissue eggs following treatment of Schistosoma japonicum infected mice. The American Journal of Tropical Medicine and Hygiene 40:620-628, 1989.

9. Colley $D G$, Todd $C W$, Lewis FA, Goodgame $R W$. Immune responses during human schistosomiasis mansoni. VI In vitro nonspecific suppression of phytohemagglutinin responsiveness induced by exposure to certain schistosomal preparations. Journal of Immunology 122: 1447-1453, 1979.

10. Cottrell BJ, Humber D, Sturrock RF, Seitz H, Rees P. Non-specific cell mediated immunity in patients infected with Schistosoma mansoni in Kenya. Transactions of the Royal Society of Tropical Medicine and Hygiene 76: 234-237, 1982.

11. Coutinho AD, Antunes MTA, Domingues ALC. Estudo da imunidade humoral e celular na doença hepática esquistossomótica. Revista do Instituto de Medicina Tropical de São Paulo 24: 282-291, 1982.

12. Gutteridge F. Human experimentation and medical ethics international guidelines for biomedical research involving human subjects. World Health Organization Chronicle 35: 212-215, 1981.

13. Hahn H, Kaufmann SHE. The role of cell-mediated immunity in bacterial infections. Reviews of Infectious Diseases 3: 1221-1250, 1981.

14. Katz N, Chaves A, Pellegrino J. A simple device for quantitative stool thick-smear technique in schistosomiasis mansoni. Revista do Instituto de Medicina Tropical de São Paulo 14: 397-400, 1972.

15. Kumada M, Hosaka Y, Kawabata M, Asahi H, Kato K, Kobayakawa T, Hayashi S. Recovery from immunesupression in mice infected with Schistosoma iaponicum by treatment of praziquantel. Japanese Journal of Medical Science and Biology 40: 89-93, 1987.

16. Mota-Santos TA, Tavares CAP, Gazzinelli G, Pellegrino J. Immunosuppression mediated by adult worms in chronic schistosomiasis mansoni. The American Journal of Tropical Medicine and Hygiene 26: 727-731, 1977.

17. Muniz-Junqueira MI. Resposta imune e atividade de macrófagos para Salmonella na esquistossomose mansoni. Tese de Mestrado, Universidade de Brasilia, Brasilia, 1987.

18. Muniz-Junqueira MI, Tosta CE, Prata A. T cell-dependent immunodepression in vivo in Schistosoma mansoni-infected patients. Revista da Sociedade Brasileira de Medicina Tropical 23: 27-31, 1990.

19. Prata A. Como caracteriza a forma hepato-esplênica da esquistossomose? In: II Simpósio sobre Esquistossomose, Salvador p. 179, 1970.

20. Rosen FS, Wedgwood RJ, Eibl M. Primary immunodeficiency diseases. Clinical Immunology and Immunopathology 40: 166-196, 1986.

21. Tawfik AF, Carter CE, Colley DG. Effects of antischistosomal chemotherapy on immune responses, protection and immunity. I Changes in cellular and humoral responses. The American Journal of Tropical Medicine and Hygiene 35: 100-109, 1986.

22. Teixeira RS. Associação de infecção por $S$. mansoni e bacteremia prolongada por enterobactérias. In: Aspectos peculiares da infecção por $S$. mansoni. CEDRE, Universidade Federal da Bahia p. 35-102, 1984. 